\title{
MONITORING KEGIATAN REBOISASI KEBUN RAYA BALI TERHADAP \\ TANAMAN LANGKA DAN BERPOTENSI DI BEBERAPA KABUPATEN TABANAN DAN BULELENG, BALI
}

\author{
MONITORING IN REFORESTATION ACTIVITIES OF RARE AND \\ POTENTIAL PLANTS IN BALI BOTANICAL GARDEN'S COLLECTION
}

\author{
Dyan M. S. Putri* dan Ahmad Fauzi \\ Balai Konservasi Tumbuhan Kebun Raya "Eka Karya” Bali - LIPI, \\ Candikuning, Baturiti, Tabanan, Bali 82191 \\ E-mail: dyan.ari79@gmail.com
}

Diterima 2 Pebruari 2018 Disetujui 22 Desember 2018

\section{INTISARI}

Perubahan fungsi lahan hutan dapat menyebabkan keberadaan tumbuhan jenis endemik bahkan yang unik terancam punah di alam. Kegiatan reboisasi dilakukan sejak tahun 2003 dan monitoring dilakukan bertujuan untuk mengetahui kualitas dan kuantitas pertumbuhan tanaman sehingga dapat diantisipasi cara penanggulangannya dan tindak lanjut kegiatan selanjutnya. Kegiatan monitoring dilakukan dengan observasi dan dilakukan dalam kurun waktu empat tahun dari 2013 hingga 2016. Lokasi kegiatan dilakukan di beberapa lokasi penanaman di Kabupaten Tabanan dan Kabupaten Buleleng. Material yang dimonitor adalah 36 jenis tanaman yang telah ditanam sebagai tanaman reboisasi. Data yang didapatkan berupa data persentase hidup dan tinggi tanaman (meter) dan dianalisis secara deskriptif. Dari hasil kegiatan ini diketahui bahwa tingkat keberhasilan tanaman reboisasi yang berhasil hidup dari jenis terpilih adalah Dacrycarpus imbricatus (Blume) de Laubenf 72\%, Elaeocarpus grandiflorus J.E.Sm. 70\%, Michelia champaca L. 73\%; dan Casuarina junghuhniana Miq. 56\%. Melalui kegiatan ini juga diharapkan mampu menyelamatkan Dacrycarpus imbricatus (Blume) de Laubenf, Elaeocarpus grandiflorus J.E.Sm., dan Michelia champaca L. yang mulai sulit ditemukan di masyarakat.

Kata kunci: Kebun Raya Bali, monitoring, reboisasi, tanaman langka

\begin{abstract}
Changes in the function of forest land can lead to the existence of even unique endemic species threatened with extinction in nature. Reforestation and monitoring activities were conducted to determine the condition of the crop (plant growth and the percentage of growing plants) so that it can be anticipated the way of handling it and follow up the next activity. Reforestation activities have been conducted since 2003 and monitoring activities were conducted within four years from 2013 to 2016. The location of the activities was done in several planting locations in Tabanan and Buleleng districts. The material used was 36 types of plants that are the result of Bali Botanic Gardens propagation. Data obtained in the form of percentage data of life and plant height (meters) and analyzed descriptively. From the results of this activity it was known that the success rate of successful reforestation plant of selected species were Dacrycarpus imbricatus (Blume) de Laubenf 72\%, Elaeocarpus grandiflorus J.E.Sm. 70\%, Michelia champaca L. 73\%; berulang and Casuarina junghuhniana Miq. 56\%. This activity is also expected to save Dacrycarpus imbricatus (Blume) de Laubenf, Elaeocarpus grandiflorus J.E.Sm., and Michelia champaca L.
\end{abstract}

Keywords: Bali Botanic Gardens, monitoring, reforestation, rare plants

\section{PENDAHULUAN}

Indonesia diperkirakan memiliki 35.0oo-40.00o jenis tumbuhan atau setara dengan $13-15 \%$ jenis tumbuhan yang ada di dunia dan 18.700 jenis diantaranya diperkirakan sebagai tumbuhan endemik Indonesia. Namun, baru $1 / 3$ dari jumlah jenis tumbuhan tersebut yang sudah teridentifikasi dan terdokumentasi. Disisi lain, terdapat berbagai faktor yang mengancam kelestarian keanekaragaman tumbuhan di Indonesia. Ancaman tersebut berasal dari faktor intrinsik biologi tumbuhan (sebesar 83\%), kerusakan habitat (82\%), eksploitasi berlebihan (62\%) dan bencana alam (6\%) (Bappenas, 2003; Budiharta et al., 2011, Widjaja et al., 2011). Faktor intrinsik biologi tumbuhan meliputi ukuran populasi yang kecil, luas sebaran yang terbatas, habitat yang spesifik, kendala reproduksi dan kebutuhan simbiosis. Sementara kerusakan habitat disebabkan oleh kegiatan transmigrasi, pembangunan pemukiman dan infrastruktur, hutan 
tanaman industri, perkebunan, pertanian, pertambangan, pencurian kayu dan penebangan liar (Surya et, al., 2013).

Potensi flora endemik banyak digunakan sebagai tumbuhan hias, tumbuhan buah, tumbuhan obat, konstruksi dan tumbuhan untuk keperluan upacara adat, sehingga perlu dilindungi dari laju kepunahan yang semakin cepat. Kebun Raya Bali sebagai lembaga konservasi ex-situ mempunyai tugas melakukan inventarisasi, eksplorasi dan konservasi tumbuhan tropika yang mempunyai nilai ilmu pengetahuan dan berhabitat di dataran tinggi kering, khususnya Indonesia bagian Timur. Kebun Raya Bali juga memiliki fungsi yakni melakukan jasa ilmiah di bidang arsitektur lansekap pertamanan, ragam tanaman hias, introduksi daya guna flora yang berhabitat di dataran tinggi kering dan pelayanan jasa untuk menumbuhkan apresiasi masyarakat terhadap alam lingkungan tropika (Anonim, 1999).

Salah satu kegiatan yang telah dilakukan Kebun Raya Bali adalah melakukan perbanyakan, donasi dan monitoring tanaman langka yang berpotensi. Hal ini dilakukan untuk menggiatkan kegiatan reboisasi sebagai salah satu upaya untuk menekan tingkat kehancuran jenisjenis tanaman langka dan berpotensi sekaligus memberikan pendidikan konservasi bagi masyarakat tentang pentingnya pelestarain sumber daya alam hayati.

Kegiatan reboisasi tanaman langka dan berpotensi ini sudah dilakukan sejak tahun 2003 namun baru dilakukan kegiatan monitoring sejak tahun 2010. Kegiatan ini mencakup wilayah di Bali yang meliputi kawasan hutan lindung, laba pura, lingkungan sekolah dan lingkungan masyarakat. Kegiatan monitoring dilakukan untuk mengetahui perkembangan tanaman yang sudah ditanam di daerah-daerah tersebut. Kegiatan ini sangat penting dilakukan karena dapat digunakan sebagai indikator keberhasilan kegiatan reboisasi (pasca pelepasan/penanaman) yang meliputi kesehatan dan ke individu (direct tagging, telemetry atau pelibatan informan), melakukan re-inforcement individu-individu yang dilepas (proses adaptasi, mortalitas, ancaman, hama dan penyakit), melakukan revisi program (penghentian bila diperlukan), melindungi habitat (penjagaan, aspek legal), melanjutkan kegiatan public relations dan pendidikan, melakukan evaluasi teknik reintroduksi, serta melakukan publikasi (Widyatmoko dan Irawati, 2007). Kegiatan ini dilakukan bertujuan untuk mengetahui kondisi tanaman (pertumbuhan tanaman dan persentase tanaman yang tumbuh) sehingga dapat diantisipasi cara penanggulangannya dan tindak lanjut kegiatan selanjutnya.

\section{BAHAN DAN METODE}

Kegiatan reboisasi dan monitoring ini dilakukan dengan mengikuti tahapan sederhana re-introduksi yang meliputi tahap persiapan (pre-activities), tahap pelapasan/penanaman (released stage) dan tahap pasca pelepasan (post-released stage) (Widyatmoko dan Irawati, 2007).
Kegiatan reboisasi telah dilakukan sejak tahun 2003 dan kegiatan monitoring dilakukan dalam kurun waktu empat tahun dari 2013 hingga 2016. Pengamatan yang dilakukan pada saat monitoring meliputi pengukuran tinggi tanaman (meter) dan jumlah tanaman yang berhasil tumbuh (persentase), serta observasi terhadap kondisi tanaman (penyebab kematian tanaman yang meliputi: kering, dimakan ternak, tidak ditemukan). Lokasi kegiatan dilakukan di beberapa lokasi penanaman di Kabupaten Tabanan meliputi Kecamatan Baturiti, Kecamatan Marga, Kecamatan Penebel, dan Kecamatan Selemadeg dan Kabupaten Buleleng meliputi Kecamatan Sukasada, Kecamatan Sawan, Kecamatan Gerokgak dan Kecamatan Banjar. Material yang digunakan adalah 36 jenis tanaman yang merupakan hasil perbanyakan Kebun Raya Bali (Lampiran 1.) sedangkan untuk pengamatan autekologi dilakukan pada jenis-jenis terpilih meliputi Dacrycarpus imbricatus (Blume) de Laubenf, Elaeocarpus grandiflorus J.E.Sm., Michelia champaca L.; dan Casuarina junghuhniana Miq. dengan melakukan observasi dan studi pustaka.

\section{HASIL}

Dari hasil pengamatan, persentase hidup dari jenis terpilih adalah Dacrycarpus imbricatus (Blume) de Laubenf 72\%, Elaeocarpus grandiflorus J.E.Sm. 70\%, Michelia champaca L. 73\%; dan Casuarina junghuhniana Miq. 56\%. Faktor yang diduga menyebabkan kematian bibit adalah karena adanya kompetisi nutrisi dengan rumput gajah dan adanya naungan oleh Rauvolfia sp. dewasa yang sangat banyak dijumpai di lokasi penanaman. Selain kedua hal di atas, faktor lain penyebab kematian bibit yang ditanam di sekitar danau Bratan dan danau Buyan disebabkan karena bibit terendam pada saat air danau pasang, dan kurangnya pemeliharaan secara rutin pada saat bibit baru ditanam.

\section{PEMBAHASAN}

Kegiatan reboisasi dan monitoring ini merujuk pada tahapan re-introduksi meliputi tahap persiapan (preactivities) meliputi studi autekologi dan perbanyakan bibit; tahap pelepasan/penanaman (released stage); dan tahap pasca pelepasan (post-released stage) meliputi monitoring pertumbuhan bibit serta pendidikan konservasi (Widyatmoko dan Irawati, 2007).

Tanaman tersebut merupakan hasil dari perbanyakan di Kebun Raya Bali. Perbanyakan dilakukan secara konvensional melalui biji dengan beberapa tahap yaitu seleksi induk untuk dipanen bijinya, biji dipanen dari buah yang telah masak yang kemudian dikeringkan dengan dijemur. Setelah itu biji disemai di penyemaian dengan media pasir. Biji mulai berkecambah setelah empat minggu sekitar 80\% (Lampiran 1.). Setelah itu dipindahkan ke polybag yang telah berisi media humus dan pupuk 'KOMPENIT'. Pemindahan ini bertujuan untuk menunjang pertumbuhan dan perkembangan akar serta mencukupi kebutuhan tanaman akan air dan unsur hara (Putri, 2006). 
Studi autekologi bertujuan untuk mengetahui interaksi dengan habitat atau lingkungan yang meliputi dinamika dan status populasi, demografi, preferensi habitat, interaksi dengan komponen abiotik, asosiasi serta ekofisiologi pada satu atau lebih spesies tertentu (Sutomo, 2014, Widyatmoko dan Irawati, 2007). Pada kegiatan ini studi autekologi tidak dilakukan pada semua jenis yang disumbangkan namun pada beberapa jenis terpilih antara lain Dacrycarpus imbricatus (Blume) de Laubenf, Dysoxylum caulostachyum Miq., Elaeocarpus grandiflorus J.E.Sm., dan Michelia champaca L. dan Casuarina junghuhniana Miq. Pemilihan jenis ini dilakukan karena Dacrycarpus imbricatus (Blume) de Laubenf, Elaeocarpus grandiflorus J.E.Sm., Michelia champaca L.; Dysoxylum caulostachyum Miq. dan Casuarina junghuhniana Miq. merupakan tanaman yang pernah mendominasi kawasan Hutan Lindung Batukaru, khususnya kawasan - kawasan yang masih belum/jarang terkena aktivitas masyarakat sekitar, sedangkan Michelia champaca L., sangat jarang dijumpai di kawasan tersebut. Michelia champaca L. selama ini memang lebih banyak ditemui di pekarangan rumah penduduk.

\section{Tinjauan Umum Jenis Terpilih}

Dacrycarpus imbricatus (Blume) de Laubenf yang lebih dikenal nama daerah cemara pandak dan jamuju ini memiliki sinonim Podocarpus imbricatus Blume, Podocarpus javanicus auct non (Burm.f) Merr. D. imbricatus memiliki persebaran yang cukup luas yaitu dari Cina Selatan, Indo-Cina, Myanmar, Thailand juga ke seluruh kepulauan Malesia hingga ke Kepulauan Vanuatu dan Fiji. Di Indonesia, cemara pandak tersebar dari mulai dari Bagian Barat hingga Indonesia Timur, mulai dari Sumatra, Jawa, Kalimantan, Sulawesi, Bali, NTB, NTT dan Papua. Dacrycapus biasanya dijumpai tumbuh di hutan hujan tropis dalam pola yang tersebar (scattered) akan tetapi terkadang juga menjadi jenis dominan dan sangat jarang sekali tumbuh sebagai tegakan murni. Banyak dijumpai di habitat sub-montane ataupun habitat montane pada ketinggian 800-2.500 dan terkadang $3.600 \mathrm{~m} \mathrm{dpl}$, namun pada tempat yang makin tinggi, ukurannya tidak ada yang sebesar yang tumbuh pada ketinggian $800-$ $2.500 \mathrm{~m}$ dpl (Lemmens et al., 1995; Rahadiantoro et al,. 2013; Su, 2010).

Tumbuhan ini dapat mencapai tinggi $50 \mathrm{~m}$ dengan diameter batang dapat mencapai $200 \mathrm{~cm}$. Daunnya menyebar, tegak seperti duri dengan ukuran 1,0-1,8 mm x o,4-1,0 mm. Biji berukuran panjang $6 \mathrm{~mm}$. Cemara pandak adalah sumber kayu Podocarp yang penting dan banyak digunakan untuk berbagai keperluan seperti furniture. Pertambahan diameter tahunan cemara pandak di hutan alam dilaporkan sekitar 0,7-2,1 mm/tahun. Tumbuhan ini penyerbukannya dibantu dengan angin dan mulai berbunga sekitar Bulan Januari hingga Mei dan biji mulai masak pada Bulan Maret hingga September. Bintil akar atau root nodules dilaporkan terdapat pada tumbuhan ini namun belum diketahui apakah terjadi fiksasi Nitrogen (Lemmens et al, 1995).
Dysoxylum caulostachyum Miq. yang dikenal dengan nama lokal majegau adalah flora maskot Provinsi Bali. Selain di Bali, dapat pula ditemukan di Sumatera dan Sulawesi. Tumbuhan ini bisa mencapai tinggi 30-40 m, dengan diameter batang sekitar $120 \mathrm{~cm}$. Batangnya termasuk jenis kayu yang keras dan awet, dengan warna coklat kuning muda sampai merah muda atau coklat merah muda. Di Bali, kayu majegau sering digunakan sebagai bahan pembangun pura, bahan kerajinan atau tiang rumah (Widyastuti dalam Hardini, 2004). Batang tanaman ini merupakan simbolisasi Bhatara Sadasiwa (Nala, 2004), sehingga digunakan dalam upacara manusa yadnya, yaitu upacara yang ditujukan untuk manusia. Kayunya digunakan sebagai kayu bakar upacara karena baunya yang harum (Sumantera, 2004). Selain itu, tanaman ini juga berpotensi obat, khususnya untuk penyakit sulit buang air (Lugrayasa, 2007; Su, et al. 2010; Sutomo, 2014).

Elaeocarpus grandiflorus J.E.Sm. yang lebih dikenal dengan nama rejasa (Bali) dan anyang-anyang (Jawa) merupakan pohon dengan tinggi 6-26 m. Daun bertangkai, berjejal pada ujung ranting, bentuk lanset, beralih demi sedikit pada tangkai, 5-20 kali 1-5 cm, gundul, seperti kulit, bergerigi beringgit tidak dalam. Tandan bunga menggantung, berbunga 4-6, panjang 2-10 $\mathrm{cm}$. Tangkai bunga 3-4,5 cm. Daun kelopak merah cerah, berambut. Daun mahkota putih, pada pangkalnya dengan sisik, ke arah ujung melebar sekali dan terbagi dalam taju, panjang; 2-2,5 cm. Dasar bunga kuning, kemudian oranye. Tonjolan dasar bunga berambut halus (seperti bulu anak ayam) rapat. Benang sari seluruhnya berambut. Bakal buah bentuk telur, berambut; kepala putik tidak melebar. Buah bentuk spul, hijau pucat, panjang $3 \mathrm{~cm}$ (Rohandi \& Gunawan, 2013; Sutomo, 2014).

Asal dan penyebaran geografis terdiri dari kira-kira 300 spesies terdapat mulai dari Madagaskar dan Mauritius sampai ke Sri Lanka, Indo-Cina, Cina, Jepang, Thailand, di seluruh wilayah Malesian, ke timur sampai Hawaii dan Polynesia (kira-kira 250); Papua New Guinea memiliki sekitar 70 spesies, Borneo setidaknya ada 50 dan Semenanjung Malaysia sekitar 30. Elaeocarpus banyak ditemukan di hutan primer tapi lebih sering di hutan hujan yang hidup kembali setelah bencana, pada ketinggian hingga mencapai $3.500 \mathrm{~m}$ dpl. Di Papua New Guinea, dapat secara lokal biasa ditemui di hutan montane dalam gabungan dengan Nothofagus. Tanaman ini mungkin terdapat secara berkelompok dan ditemukan di batasan yang luas suatu habitat termasuk hutan pantai, hutan rawa air tawar, kerangas dan tanah ultrabasic.

Di Indonesia dan Malaysia, kulit batang dan daun digunakan sebagai tapel dan ekstraknya diminum sebagai tonik (obat yang menguatkankan dan merangsang selera makan, di Jawa digunakan untuk mengatasi sariawan. Di Sumatera, infusa dari parutan kulit kayu dari diminum untuk demam, dan remukan daun muda, dioleskan di dahi untuk mengobati sakit kepala. Bunga tanaman ini juga berpotensi sebagai obat diabetes. Kayu digunakan untuk kontstruksi interior ringan dan kayu triplek/lapis. Cocok untuk membuat papan partikel, papan serat dan bubur kertas. Selain itu dimanfaatkan juga untuk reboisasi karena 
memiliki perawakan tinggi besar dan kanopi yang rapat, tanaman hias serta sarana upacara agama Hindu (Manusa Yadnya dan Pitra Yadnya) (http://www.proseanet .org/ prohati4/browser.php?docsid=445; Bhualee, et al. , 2007).

Michelia champaca L. biasa disebut cempaka kuning merupakan pohon berukuran sedang dengan tinggi sampai $50 \mathrm{~m}$ dan diameter, batangnya sampai $180 \mathrm{~cm}$. Batang lurus, bulat, kulit batangnya halus, berwarna coklat ke abuabuan. Tajuknya agak jarang, dan agak melebar, dengan percabangannya yang tidak teratur. Daunnya tunggal, tersusun spiral, berbentuk lanset yang agak melebar, berukuran sedang, dan berbulu halus pada permukaan bawahnya, tangkainya berbulu, stipulanya panjang seringkali melebihi tangkai daunnya. Bunga berwarna kuning muda ketika muda dan menjadi oranye tua ketika tua, harum, berukuran agak besar, helaian bunganya tersusun dalam untaian yang banyak. Buahnya coklat terdiri atas 2 - 6 biji (Taprial, 2015).

Penyebarannya luas, bahkan mencakup pula India, Indo-Cina, Indo Cina, Semenanjung Malaya, Sumatra, Jawa dan Kepulauan Sunda Kecil. Sekarang sudah umum ditanam di seluruh daerah Tropika. Tumbuh dipinggir hutan pada tanah yang subur pada ketinggian hingga 1.500 m dpl. Kayunya dapat digunakan sebagai bahan untuk membuat panel pintu dan peralatan rumah tangga, dapat digunakan sebagai campuran pada jamu atau digunakan untuk wewangian rambut atau diramu bersama bahan lain untuk dijadikan parfum, ada juga yang menyarikan minyak cempaka dari bunganya untuk dipakai dalam industri kosmetika

(http://www.proseanet.org/prohati4/browser.php?docsid =108; Ananthi \& Chitra, 2013; Sinha \& Varma, 2016).

Casuarina junghuhniana Miq. atau cemara gunung termasuk ke dalam suku Casuarinaceae. Tumbuhan ini memiliki ciri morfologi antara lain habitus pohon berukuran $25 \mathrm{~m}$, berumah 2, ranting hijau beralur 5-12, kerap kali persegi 8, tebalnya kurang dari $1 \mathrm{~mm}$. Helai daun berbentuk jarum dan tersusun berhadapan atau berseling dengan braktea bersatu. Daun pelindung buah berbentuk segitiga terbalik, lebar 0,5 mm dengan ujung duri tempel. Bunga dalam lingkaran 10 karangan bunga terdiri dari 7-8 bunga dan dalam 14-16 baris yang membujur. Buah kering berukuran 5-6 mm x 2-3 mm dengan ujung segitiga lancip, sayapnya berupa selaput, Tiap braktea dengan sejumlah biji kecil tanpa sayap. Strobilus jantan dan betina dalam satu pohon, strobilus jantan berbentuk kerucut, strobilus betina berbentuk bulat, terletak aksilaris (Jayaraj, 2016).

\section{Studi autekologi}

Studi autekologi ini dilakukan untuk mendapatkan data yang nantinya akan bermanfaat bagi perencanaan kegiatan reintroduksi/reboisasi tumbuhan. Berdasarkan PP No. 7 Tahun 1999, terdapat 54 jenis tumbuhan Indonesia yang dilindungi. Namun demikian, jumlah tersebut tidak jelas merinci jumlah jenisnya pada beberapa kelompok tumbuhan seperti Anggrek, Rafflesia, dan Nepenthes. Berdasarkan perhitungan Widjaja et al. (2011) jumlah tumbuhan yang dilindungi tersebut mencapai 109 jenis. Pada tahun 2001, Mogea et al. mengelompokkan 240 tumbuhan Indonesia sebagai tumbuhan langka, sementara itu berdasarkan kriteria IUCN Red List untuk Indonesia terdapat 687 jenis tumbuhan Indonesia yang terancam kepunahan (IUCN, 2008).

Upaya penyelamatan tumbuhan di Indonesia seharusnya mengacu pada program global seperti yang tercantum dalam Strategi Global untuk Konservasi Tumbuhan (Global Strategy for Plant Conservation/GSPC) yang saat ini memasuki tahap II (GSPC, 2012). Hal ini karena Indonesia merupakan negara yang turut serta dalam CBD 2002 dan GSPC merupakan bagian yang diadopsi oleh CBD tersebut. Dalam GSPC terdapat lima sasaran dengan 16 target dan merupakan tantangan yang harus dicapai oleh setiap negara peratifikasi CBD, termasuk Indonesia. Meskipun demikian, terdapat beberapa hambatan dalam mencapai target GSPC di Indonesia. Hambatan tersebut diantaranya yaitu belum terdapatnya Flora Indonesia yang lengkap, belum adanya National Plant Red List, belum adanya informasi dan monitoring pemanfaatan tumbuhan secara berkelanjutan, serta lemahnya perlindungan terhadap pengetahuan lokal pemanfaatan tumbuhan. Oleh sebab itu, diperlukan kebijakan yang jelas tentang strategi konservasi untuk tumbuhan Indonesia. Kerjasama berbagai institusi seperti Kebun Raya, Herbaria, Universitas, Pusat Penelitian, Pengelola Kawasan Konservasi, Eksportir/Importir produk tumbuhan, NGO di bidang lingkungan, maupun kelompok media publik, diperlukan untuk mencapai target-target konservasi tumbuhan secara efektif (Surya et al., 2013).

Dari jenis-jenis yang ditanam yaitu Dacrycarpus imbricatus (Blume) de Laubenf, Elaeocarpus grandiflorus J.E.Sm., Michelia champaca L.; Dysoxylum caulostachyum Miq. dan Casuarina junghuhniana Miq. merupakan tanaman yang pernah mendominasi kawasan Hutan Lindung Batukaru, khususnya kawasan - kawasan yang masih belum/jarang terkena aktivitas masyarakat sekitar, sedangkan Michelia champaca L., sangat jarang dijumpai di kawasan tersebut. Michelia champaca L. selama ini memang lebih banyak ditemui di pekarangan rumah penduduk. Komposisi vegetasi di kawasan Hutan Lindung Batukaru didominasi oleh Dacrycarpus imbricatus (Blume) de Laubenf dan beberapa pohon termasuk Elaeocarpus grandiflorus J.E.Sm. dengan indek diversitas berkisar antara 1,77 (anakan) - 2,11 (pohon) (Gunadi 2007, Sujarwo, 2014; Sutomo, 2014; Iryadi et al, 2017).

Dulu, majegau dapat dijumpai di sekitar desa, namun kini keberadaannya mulai langka. Demikian pula dengan populasinya di hutan. Permudaan alami tidak seimbang dengan penebangan yang dilakukan (Sumantera dan Roemantyo, 1992; Sujarwo, 2013). Sarna (2004) menggolongkan status konservasi $D$. caulostachyum ke dalam golongan genting dan E. grandiflorus ke dalam golongan rawan. Yang dimaksud genting di sini adalah tanaman yang ada dalam bahaya kepunahan dan tidak akan bisa bertahan bila faktor yang membahayakannya terus berlangsung. Sedangkan yang dimaksud rawan 
adalah tanaman akan segera masuk status genting jika faktor pengancamnya terus berlangsung. Frekuensi penggunaan dua jenis tanaman yang tergolong tinggi ini mendorong perlu dilakukannya konservasi terhadap kedua jenis tanaman ini.

Keanekaragaman jenis tumbuhan di Cagar Alam Batukaru cukup tinggi dan paling tidak terdapat 45 jenis pohon yang diantaranya termasuk jenis yang langka. Beberapa jenis yang dominan adalah bunut (Ficus indica Blanco), sompang (Laplaceae sp.), seming (Engelhardia spicata Lench.ex Bl.), cemara geseng (Casuarina junghuniana Miq.), udu (Litsea velutina Boerl.), belantih (Homalanthus giganteus Zoll. \& Mor.), lateng (Laporthea sp.) dan kedukduk (Astronia spectabilis Blume). Jenis flora yang tergolong sulit ditemui adalah cemara pandak (Dacrycarpus imbricatus (Blume) de Laubenf) walaupun menurut Thomas, P (2013) jenis ini termasuk kategori resiko rendah (Least Concern) karena sebarannya cukup luas di dunia dan kepelan (Manglietia glauca Bl.). Vegetasi lain yang dominan dan merupakan jenis yang berasosiasi dengan Dacrycarpus imbricatus (Blume) de Laubenf dan Elaeocarpus grandiflorus J.E.Sm. adalah Rauvolfia sp. dan tanaman penutup tanah seperti Lantana sp. Dacrycarpus imbricatus (Blume) de Laubenf dan Elaeocarpus grandiflorus J.E.Sm. ditemui di daerah dengan ketinggian $1.000-1.200 \mathrm{~m} \mathrm{dpl}$, ditempat terbuka hingga ternaungi $50 \%$. Penurunan populasi yang terjadi disebabkan adanya pembukaan lahan untuk pertanian, khususnya sayur - sayuran dan karena bencana alam banjir dan longsor serta penebangan pohon secara liar oleh masyarakat sekitar untuk pemenuhan kayu bakar.

Tahap berikutnya adalah kegiatan monitoring untuk memelihara dan memantau kondisi tanaman. Pengamatan dilakukan pada beberapa sampel individu. Parameter yang diamati meliputi pengamatan kondisi pertumbuhan (tinggi tanaman) (Gambar 1.) dan penghitungan prosentase hidup tanaman (Gambar 2.).

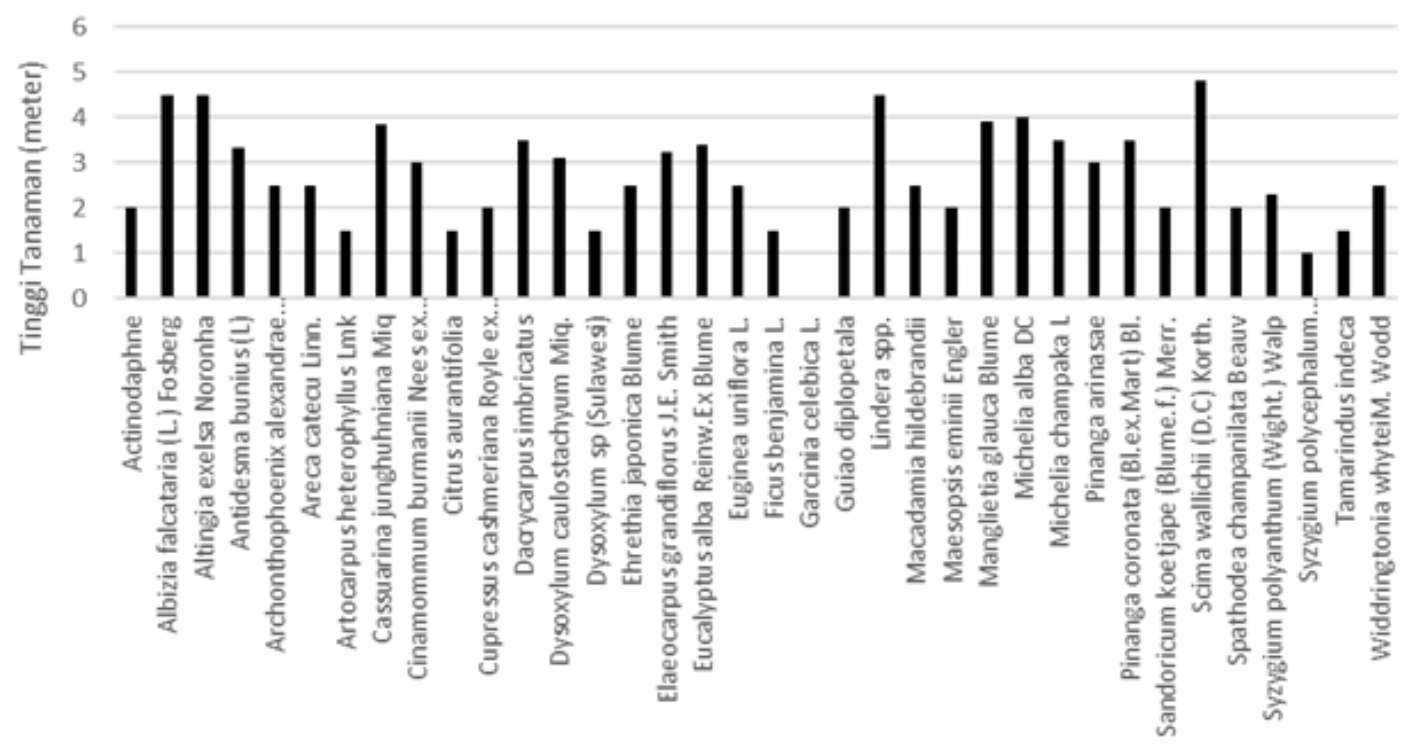

Gambar 1. Kondisi Pertumbuhan Tanaman dilihat dari Tinggi Tanaman

Dari hasil kegiatan ini diketahui bahwa kondisi pertumbuhan dan tinggi tanaman dari jenis terpilih; untuk tinggi tanaman Dacrycarpus imbricatus (Blume) de Laubenf 3,5 meter, Elaeocarpus grandiflorus J.E.Sm. 3,23 meter, Michelia champaca L. 3,5 meter; Dysoxylum caulostachyum Miq. 3,1 meter, dan Casuarina junghuhniana Miq. 3,84 meter. Dari hasil pengamatan tersebut kelima jenis terpilih ini kondisi pertumbuhannya baik, daun dan batang tumbuh segar dan sehat (tidak didapati hama/penyakit). Kondisi ini disebabkan karena tanaman ini dapat beradaptasi dengan baik dan lingkungan tempat hidupnya sesuai.
Dari hasil kegiatan ini diketahui bahwa tingkat keberhasilan tanaman reboisasi yang berhasil hidup dari jenis terpilih adalah Dacrycarpus imbricatus (Blume) de Laubenf 72\%, Elaeocarpus grandiflorus J.E.Sm. 70\%, Michelia champaca L. 73\%; Dysoxylum caulostachyum Miq. $\quad 72 \%, \quad$ dan Casuarina junghuhniana Miq. 56\%. Keberhasilan hidup tanaman ini sangat dipengaruhi oleh lingkungan yang sesuai dan untuk Casuarina junghuhniana Miq. Keberhasilan hidupnya hanya $56 \%$ karena lokasi penanaman tepat di tepi danau sehingga pada saat terjadi pasang air danau tanaman tersebut terendam dan menyebabkan akar mengalami kebusukan. 


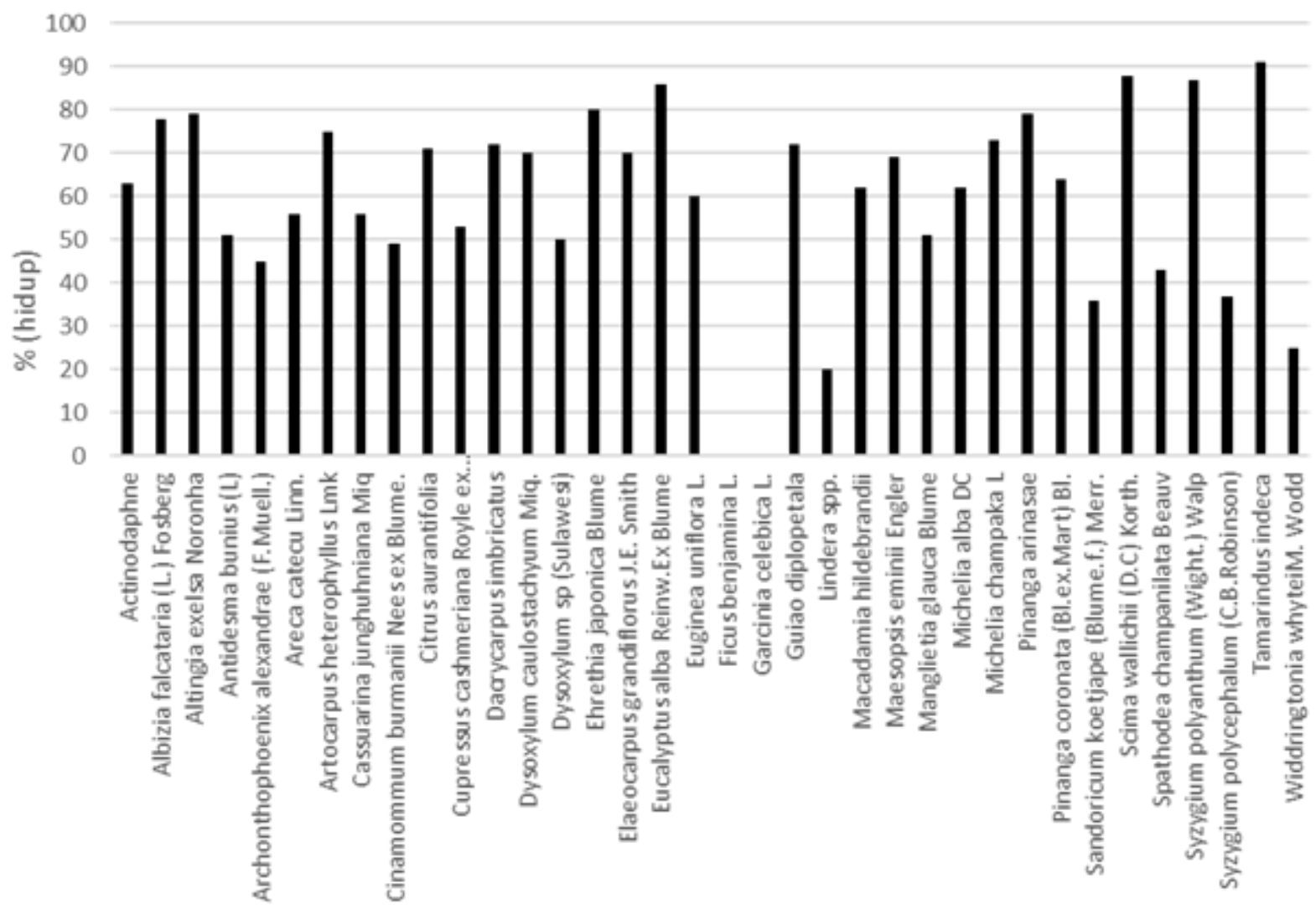

Gambar 2. Kondisi Pertumbuhan Tanaman dilihat dari Persentase Tumbuh

\section{Pendidikan Konservasi}

Saat ini, upaya konservasi oleh masyarakat memang belum secara khusus dilakukan, baru dilakukan pada tahap membudidayakan tanaman tersebut di areal pribadi untuk memenuhi kebutuhan sendiri (Windia, 2004). Secara tidak langsung, upaya ini dapat pula dikatakan sebagai kegiatan konservasi. Masyarakat tidak perlu mengeksploitasinya langsung di hutan karena sekitar perkampungan telah tersedia. Selain itu, komunitas adat Bali juga membudidayakan tanaman ini di dalam lingkungan pura, mensakralkannya dan melarang pengeksploitasiannya untuk tujuan ekonomis.

Sejauh ini, upaya pembudidayaan jenis-jenis tanaman tersebut dilakukan melalui biji. Produksi biji yang hanya terjadi di waktu tertentu, tentu menghambat dilakukannya budidaya sepanjang tahun. Agar produktifitas budidaya meningkat, informasi mengenai daya hidup biji sangat diperlukan.

Pendidikan konservasi merupakan salah satu solusi dalam upaya penyadaran terhadap pentingnya menjaga lingkungan yang diharapkan mampu memberikan pemahaman kepada masyarakat tentang pentingnya konservasi, khususnya sumber daya hayati dan sekaligus mengajak seluruh elemen masyarakat untuk berperan aktif dalam usaha konservasinya. Pemanfaatan kekayaan hayati secara bijak akan meningkatkan kesejahteraan masyarakat dan sebaliknya jika pemanfaatan dilakukan secara tidak terkendali, maka akan menyebabkan kemerosotan kualitas lingkungan hidup. Kebun raya sebagai lembaga konservasi ex situ bertanggung jawab dalam upaya menanggulangi atau mengurangi kerusakan lingkungan (Surya et al, 2013).

Peran masyarakat ditunjukkan dengan ikut aktifnya masyarakat dalam seluruh rangkaian kegiatan penanaman. Masyarakat sekitar lokasi, baik itu pemuda, para tokoh adat, bahkan petani dilibatkan mulai dari penentuan lokasi tanam, pembuatan lubang tanam, penanaman, hingga ikut serta dalam memantau pertumbuhan tanaman serta turut memelihara tanaman tersebut. Dari situlah diharapkan masayarakat mulai memahami dan turut aktif dalam kegiatan konservasi.

\section{SIMPULAN}

Dari hasil kegiatan ini diketahui bahwa tingkat keberhasilan tanaman reboisasi yang berhasil hidup dari jenis terpilih adalah Dacrycarpus imbricatus (Blume) de Laubenf $72 \%$ dengan tinggi tanaman 3,5 meter, Elaeocarpus grandiflorus J.E.Sm. $70 \%$ dengan tinggi tanaman 3,1 meter, Michelia champaca L. 73\% dengan tinggi tanaman 3,23 meter; Dacrycarpus imbricatus (Blume) de Laubenf $72 \%$ dengan tinggi tanaman 3,5 meter, dan Casuarina junghuhniana Miq. 56\% dengan tinggi tanaman 3,84 meter. Kegiatan ini juga diharapkan mampu menyelamatkan Dacrycarpus imbricatus (Blume) de Laubenf, Elaeocarpus grandiflorus J.E.Sm., dan Michelia champaca L. yang mulai sulit ditemukan di masyarakat karena tingginya penggunaan tanaman tersebut dalam 
pemenuhan kebutuhan masyarakat. Selain itu melalui kegiatan ini perlu ditekankan kepada masyarakat maupun organisasi untuk melakukan reboisasi dengan pemilihan spesies lokal (alami, asli) yang pernah ada atau masih tersisa di kawasan hutan tersebut untuk meminimalisir dampak daripada exotic invasive spesies. Dimana spesies exotic inidapat menurunkan tingkat keanekaragaman hayati di kawasan tersebut dan kepunahan spesies lokal, serta meningkatkan pemahaman tentang pentingnya konservasi sumber daya hayati secara berkelanjutan.

\section{UCAPAN TERIMA KASIH}

Penulis mengucapkan terima kasih kepada seluruh staf Unit Seleksi, Perbanyakan dan Reintroduksi Kebun Raya Bali yang telah membantu kegiatan penelitian ini.

\section{KEPUSTAKAAN}

Ananthi, T. and M. Chitra. 2013. In vitro evaluation of antioxidant activity of Michelia champaca (L.) flowers. American J.of Advanced Drug Delivery 1(5): 734-742.

Anonim, 1999. Rencana Induk Pengembangan Kebun Raya 'Eka Karya' Bali. Master Plan. UPT Balai Konservasi Tumbuhan Kebun Raya 'Eka Karya' Bali. Bali.

Bappenas. 2003. Indonesian Biodiversity Strategy and Action Plan. Dokumen Nasional. Bappenas.

Bhualee, Cunlada, Anan Qunaroon dan Rattima Jeenapongsa. 2007. Antidiabetic and long term effect of Elaeocarpus grandiflorus. Naresuan University $\mathrm{J}$. 15(1):17-28. Diakses dari www. nu.ac.th/nu_journal/pdf pada tanggal 115 Februari 2017.

Budiharta, S., D. Widyatmoko, Irawati, H. Wiriadinato, Rugayah, T. Partowihardjo, T. Uji, , A.P. Keim, and K.A. Wilson. 2011. The processes that threaten Indonesian plants. Oryx 45:175-179.

Gunadi, I.G.A. 2007. Komposisi Vegetasi Di Kawasan Hutan Lindung Batukaru (RTK.4: Desa Gesing, Kec. Banjar - Buleleng dan Desa Bukit Catu, Kec. Baturiti Tabanan). Program Studi Agronomi, Jurusan Budidaya Pertanian, Fakultas Pertanian - Unud. http://ejournal.unud.ac.id/. Diakses tanggal 2 Maret 2017.

GSPC. 2012. The Global Strategy for Plant Conservation: 2011-2025. Published by Botanic Gardens Conservation International for the Convention on Biological Diversity.

Hardini, Y. dan M.W. Proborini, 2004, Upaya pelestarian majegau flora identitas Propinsi Bali secara in vitro dalam Prosiding Seminar Konservasi Tumbuhan Upacara Agama Hindu. Bali, 7 Oktober 2004. Bali: UPT BKT KR. Eka Karya Bali. Hal.247-250.

http://www.proseanet.org/prohati4/browser.php?docsid= 445. Diakses tanggal 2 Maret 2017.

http://www.proseanet.org/prohati4/browser.php?docsid=1 o8. Diakses tanggal 2 Maret 2017.
Iryadi, R., A.Priyadi, I.D.P. Darma. 2017. Penggunaan citra satelit untuk mengetahui persebaran Dacrycarpus imbricatus (Blume) de Laub. di Bukit Tapak, Cagar Alam Batukahu Bali. J. Ilmu Kehutanan 11(2):130141.

IUCN. Conservation International and Nature Serve. 2008. Red List Category. [http://www.iucnredlist.org], Diakses pada Oktober 2013.

Jayaraj, R.S.C. 2016. Casuarina junghuhniana (Casuarinaceae) in India. Australian J.of Botany 58 (2):149-156.

Lemmens, R.H.M.J., I. Soerianegara and W.C. Wong (Eds.). 1995. Prosea 5 (2), Timber Trees: Minor Commercial Timbers. Prosea Foundation. Bogor.

Lugrayasa, I.N. 2007. Inventarisasi dan penggunaan tumbuhan obat oleh masyarakat di Kecamatan Rendang, Kabupaten Karangasem, Bali dalam Prosiding Seminar Konservasi Tumbuhan Usada Bali dan Peranannya dalam Mendukung Ekowisata. Bali, 6 September 2007. Bali: UPT. BKT. KR. Eka Karya Bali. Hal. 99-107.

Mogea, J.P., D.Gandawidjaja, H.Wiriadinata, E.N. Rusdi dan Irawati. 2001. Tumbuhan langka Indonesia. Puslitbang Biologi-LIPI. Bogor.

Nala, N. 2004. Filosofis pemanfaatan dan keanekaragaman tanaman upacara Agama Hindu di Bali dalam Prosiding Seminar Konservasi Tumbuhan Upacara Agama Hindu. Bali, 7 Oktober 2004. Bali: UPT BKT KR. Eka Karya Bali. Hal. 9-28.

Putri, D.S.M. 2006. Pengaruh jenis media terhadap pertumbuhan Begonia imperialis dan Begonia 'Bethlehem Star'. Biodiversitas 7 (2): 168 - 170.

Rahadiantoro A, E.L. Arumingtyas dan L. Hakim. 2013. Genetic variation of Dacrycarpus imbricatus in Bromo Tengger Semeru National Park (BTS-NP), East Java based on trnL (UAA) Intron Region. J.of Tropical Life Sci. 3(2):127-131.

Rohandi, A. dan G. Gunawan. 2014. Sebaran populasi dan potensi tanaman ganitri (Elaeocarpus ganitrus Roxb ) di Jawa Tengah. J.Ilmu Kehutanan 8(1):25-33.

Sarna, K. dan I.N. Sumardika. 2004. Tumbuhan upacara Agama Hindu di Bali dalam tantangan jaman dalam Prosiding Seminar Konservasi Tumbuhan Upacara Agama Hindu. Bali, 7 Oktober 2004. Bali: UPT BKT KR. Eka Karya Bali. Hal.123-126.

Sinha, R. R. and R. Varma. 2016. Michelia champaca L. (Swarna Champa): A Review. Intl. J. of Enhanced Research in Sci., Tech \& Engineering 5(8):78-83.

$\mathrm{Su}$ Y., T. Wang, F.Deng. 2010. Contrasting genetic variation and differentiation on Hainan Island and the Chinese mainland populations of Dacrycarpus imbricatus (Podocarpaceae). Biochem. Systematics and Ecol. 38:576-584.

Sujarwo, W. 2013. Klasifikasi kelimpahan tumbuhan di Kecamatan Kintamani Bali: Studi kasus usaha konservasi (abundance classification of plants in Kintamani Bali: case study for conservation efforts). J.Manusia dan Lingkungan 20(3):276-283. 
Sumantera, I.W. 2004. Peranan tanaman kehormatan dalam pelestarian tanaman upacara adat di Kebun Raya Eka Karya Bali dalam Prosiding Seminar Konservasi Tumbuhan Upacara Agama Hindu. Bali, 7 Oktober 2004. Bali: UPT BKT KR. Eka Karya Bali. Hal.81- 91.

Sumantera, I.W. dan Roemantyo. 1992. Peranan tanaman dalam upacara Ngaben di Bali dalam Prosiding Seminar dan Lokakarya Etnobotani, Bogor, 19-20 Februari 1992. Hal.161-170.

Surya, M.I., M. Lailati, I. Ekasari, Y.Nurlaeni, S. Astutik, S. Normasiwi, A.R.Gumilang, D. I.Junaedi, Z.Mutaqien, D.R. Nurdiana, W.Rahman, Destri, A.H.Rozak. 2013. Konservasi tumbuhan di Kebun Raya Cibodas sebagai penyelamat keanekaragaman hayati pegunungan di Indonesia. Lokakarya Nasional Keanekaragaman Hayati sebagai Modal Dasar Pembangunan. https://www.researchgate.net/publication/28357088 3. oktober 2013

Sutomo. 2014. Eksplorasi keberadaan tumbuhan langka lokal Bali di kawasan hutan Danau BuyanTamblingan dan beberapa desa di Kabupaten
Buleleng Bali. Jurnal Al-Azhar Indonesia Seri Sains dan Teknologi 2(4):253-259.

Taprial S. 2015. A review on phytochemical and pharmacological properties of Michelia Champaca Linn. Family: Magnoliaceae. Int. J. Pharmacognosy 2(9):430-436.

Thomas, P. 2013. Dacrycarpus imbricatus. The IUCN Red List of Threatened Species eT42445A2980614.http://dx.doi.org/10.2305/IUCN. UK.2013-1.RLTS.T42445A2980614.en. Downloaded on 15 February 2018.

Widjaja, E.A., I.Maryanto, D. Wowow \& S.N. Prijono. 2011. Status Keanekaragaman Hayati Indonesia. Jakarta: LIPI Press.

Widyatmoko dan Irawati. 2007. Kamus Istilah Konservasi. Pusat Konservasi Tumbuhan Kebun Raya Bogor. LIPI Press.Jakarta.

Windia, W.P. 2004. Kebijakan pemerintah dan partisipasi masyarakat dalam upaya mengkonservasi tanaman upakara di Bali dalam Prosiding Seminar Konservasi Tumbuhan Upacara Agama Hindu. UPT BKT Kebun Raya Eka Karya Bali. Hal.1-8. 
LAMPIRAN 1. Jenis Tanaman yang Hasil Perbanyakan Kebun Raya Bali

\begin{tabular}{|c|c|c|c|c|c|c|c|c|c|}
\hline \multirow[b]{2}{*}{ No. } & \multirow[b]{2}{*}{ Nama Tanaman } & \multirow{2}{*}{$\begin{array}{l}\text { Nama } \\
\text { Daerah }\end{array}$} & \multirow[b]{2}{*}{ Suku } & \multicolumn{3}{|c|}{ Jumlah } & \multirow{2}{*}{$\begin{array}{c}\% \\
\text { (hidup) }\end{array}$} & \multirow[b]{2}{*}{ Sebab mati } & \multirow{2}{*}{$\begin{array}{l}\text { Rerata Tinggi } \\
\text { Tanaman } \\
\text { (meter) }\end{array}$} \\
\hline & & & & Tanam & Mati & Hidup & & & \\
\hline 1 & Actinodaphne sp. & & Lauraceae & 80 & 30 & 50 & 63 & Batang mengering & 2 \\
\hline 2 & Albizia falcataria (L.) Fosberg & & Leguminaceae & 150 & 33 & 117 & 78 & Tidak ditemukan & 4.5 \\
\hline 3 & Altingia exelsa Noronha & Rasmala & Altingiaceae & 1100 & 235 & 865 & 79 & Tidak ditemukan & 4.5 \\
\hline 4 & Antidesma bunius (L) & Buni & Euphorbiace & 2062 & 1008 & 1054 & 51 & Dimakan ternak & 3.33 \\
\hline 5 & Archonthophoenix alexandrae (F.Muell.) & $\begin{array}{l}\text { Palm } \\
\text { Aleksander }\end{array}$ & Arecaceae & 516 & 286 & 230 & 45 & Batang mengering & 2.5 \\
\hline 6 & Areca catecu Linn. & $\begin{array}{l}\text { Palm } \\
\text { Aleksander }\end{array}$ & Arecaceae & 52 & 23 & 29 & 56 & Batang mengering & 2.5 \\
\hline 7 & Artocarpus heterophyllus Lmk & $\begin{array}{l}\text { Palm } \\
\text { Aleksander }\end{array}$ & Arecaceae & 20 & 5 & 15 & 75 & Batang mengering & 1.5 \\
\hline 8 & Casuarina junghuhniana Miq & $\begin{array}{l}\text { Cemara } \\
\text { Geseng }\end{array}$ & Casuarinaceae & 255 & 113 & 142 & 56 & Batang mengering & 3.84 \\
\hline 9 & Cinamommum burmanii Nees ex Blume. & $\begin{array}{l}\text { Kayu } \\
\text { Manis }\end{array}$ & Lauraceae & 1182 & 600 & 582 & 49 & Batang mengering & 3 \\
\hline 10 & Citrus aurantifolia & Jeruk & Rutaceae & 96 & 28 & 68 & 71 & Tidak ditemukan & 1.5 \\
\hline 11 & Cupressus cashmeriana Royle ex Carriere & & Cupressaceae & 62 & 29 & 33 & 53 & Batang mengering & 2 \\
\hline 12 & Dacrycarpus imbricatus & $\begin{array}{l}\text { Cemara } \\
\text { pandak }\end{array}$ & Podocarpaceae & 1138 & 317 & 821 & 72 & Batang mengering & 3.5 \\
\hline 13 & Dysoxylum caulostachyum Miq. & Majegau & Meliaceae & 1894 & 565 & 1329 & 70 & Batang mengering & 3.1 \\
\hline 14 & Dysoxylum sp (Sulawesi) & Majegau & Meliaceae & 500 & 250 & 250 & 50 & Tidak ditemukan & 1.5 \\
\hline 15 & Ehrethia japonica Blume & & Boraginaceae & 50 & 10 & 40 & 80 & Tidak ditemukan & 2.5 \\
\hline 16 & Elaeocarpus grandiflorus J.E. Smith & Rijasa & Elaeocarpaceae & 1469 & 438 & 1031 & 70 & Batang mengering & 3.23 \\
\hline 17 & Eucalyptus alba Reinw.Ex Blume & & Myrtaceae & 125 & 17 & 108 & 86 & Batang mengering & $3 \cdot 4$ \\
\hline 18 & Euginea uniflora L. & & Myrtaceae & 10 & 4 & 6 & 60 & Tidak ditemukan & 2.5 \\
\hline 19 & Ficus benjamina L. & & Moraceae & 25 & 25 & $\mathrm{O}$ & 0 & Tidak ditemukan & 1.5 \\
\hline 20 & Garcinia celebica $\mathrm{L}$. & & Clusiaceae & 1 & 1 & 0 & 0 & Tidak ditemukan & 0 \\
\hline 21 & Guiao diplopetala & & Sapindaceae & 178 & 50 & 128 & 72 & Batang mengering & 2 \\
\hline 22 & Lindera spp. & & Lauraceae & 50 & 40 & 10 & 20 & Tidak ditemukan & 4.5 \\
\hline 23 & Macadamia hildebrandii & & Proteaceae & 13 & 5 & 8 & 62 & Dimakan ternak & 2.5 \\
\hline 24 & Maesopsis eminii Engler & & Rhamnaceae & 80 & 25 & 55 & 69 & Tidak ditemukan & 2 \\
\hline
\end{tabular}




\begin{tabular}{|c|c|c|c|c|c|c|c|c|c|}
\hline \multirow{2}{*}{ No. } & \multirow{2}{*}{ Nama Tanaman } & \multirow{2}{*}{$\begin{array}{l}\text { Nama } \\
\text { Daerah }\end{array}$} & \multirow{2}{*}{ Suku } & \multicolumn{3}{|c|}{ Jumlah } & \multirow{2}{*}{$\begin{array}{c}\% \\
\text { (hidup) }\end{array}$} & \multirow{2}{*}{ Sebab mati } & \multirow{2}{*}{$\begin{array}{l}\text { Rerata Tinggi } \\
\text { Tanaman } \\
\text { (meter) }\end{array}$} \\
\hline & & & & Tanam & Mati & Hidup & & & \\
\hline 25 & Manglietia glauca Blume & Kepalan & Magnoliaceae & 770 & 375 & 395 & 51 & $\begin{array}{l}\text { Batang } \\
\text { mengering/layu/me } \\
\text { ranggas }\end{array}$ & $3 \cdot 9$ \\
\hline 26 & Michelia alba DC & $\begin{array}{l}\text { Cempaka } \\
\text { putih }\end{array}$ & Magnoliaceae & 400 & 154 & 246 & 62 & Batang mengering & 4 \\
\hline 27 & Michelia campaka L & $\begin{array}{l}\text { Cempaka } \\
\text { kuning }\end{array}$ & Magnoliaceae & 918 & 250 & 668 & 73 & Batang mengering & 3.5 \\
\hline 28 & Pinanga arinasae & Nyabah & Arecaceae & 510 & 107 & 403 & 79 & Batang mengering & 3 \\
\hline 29 & Pinanga coronata (Bl.ex.Mart) Bl. & & Arecaceae & 55 & 20 & 35 & 64 & Batang mengering & $3 \cdot 5$ \\
\hline 30 & Sandoricum koetjape (Blume.f.) Merr. & Sentul & Meliaceae & 85 & 54 & 31 & 36 & Batang mongering & 2 \\
\hline 31 & Scima wallichii (D.C) Korth. & Puspa & Theaceae & 50 & 6 & 44 & 88 & Batang mengering & 4.8 \\
\hline 32 & Spathodea champanulata Beauv & & Bignoniaceae & 437 & 250 & 187 & 43 & Batang mengering & 2 \\
\hline 33 & Syzygium polyanthum (Wight.) Walp & Salam & Myrtaceae & 492 & 65 & 427 & 87 & Batang mengering & 2.3 \\
\hline 34 & Syzygium polycephalum (C.B.Robinson) & Salam & Myrtaceae & 203 & 128 & 75 & 37 & Batang mengering & 1 \\
\hline 35 & Tamarindus indica & Asam & Leguminoceae & 150 & 13 & 137 & 91 & Batang mengering & 1.5 \\
\hline 36 & Widdringtonia whytei Rendle & & Cupressaceae & 12 & 9 & 3 & 25 & Batang mengering & 2.5 \\
\hline
\end{tabular}

